\title{
Finance and Growth: Modern Interpretations of the
}

\section{Thoughts of Schumpeter}

\author{
Eliana Lauretta ${ }^{1}$
}

\begin{abstract}
Studies of the 2007- 09 credit crisis and the resulting recession have revealed the inadequacy of the predominant theoretical frameworks and their failure to propose adequate policy solutions. The presence in the economy of "bank money" and a financial system (not only constituted by banks) characterized by financial innovation and speculation fundamentally changes the nature of credit creation. As J.A. Schumpeter (1934) [1] and others scholars (such as Shackle, 1967)[2] have recognized the central role of credit creation in the economic system, a new perspective on the financial role in defining the growth path needs to be developed by filling the gaps in New Growth Theory (NGT) (Aghion and Howitt, 1998)[34] and Evolutionary Theory (ET) (Nelson and Winter, 1982)[4] - which we call the two Sons of Schumpeter - and in some way combining them. The financial instability of the economy seems to depend on the financial structure. The goal of this survey is to explain the main hypothesis of the historical passage of the economy from a virtuous to a bad cycle and to show the existence of what we label the wealth trap: that is, the consequence of the presence of a technologically advanced and greedy financial system within the economic system. This new point of view can help to answer some important questions that in the literature remain unsolved. Future extensions of this survey will develop a quantitative ABM (Agent-Based Model) able to demonstrate the existence of the "two cycles" and will finally undertake experiments to build policy proposals for the restoration of the virtuous cycle and to prevent this cycle from becoming a bad one again.
\end{abstract}

${ }^{1}$ Eliana Lauretta, Business School, Department of Finance, University of Birmingham (e.lauretta@bham.ac.uk) 
JEL codes: (011, E02, O43, E44, G24, E32, E50 )

Keywords: Finance, Growth, Innovation, Financial Innovation, New Growth Theory, Evolutionary Theory.

\section{Introduction}

Why is it so important to understand the link between finance and growth? The 2007-2009 crisis, when systematic issues triggered by the financial system disturbed the real economy, has inspired this study. Minksy (1982)[5] defines the role of lenders as "endogenously destabilizing". The characteristics of this kind of crisis are the evolution from a typical financial crisis to a real economic crisis. Usually, political economy analysis has a monetarist or neoclassical footprint, such as that used in the European context. However, the recent chain of events questions the validity and efficacy of this standard approach. The notion of the "neutrality of finance" (Modigliani-Miller, 1958)[6] or the "independence of the money making process from the credit making process" (underlying the mainstream theory of the finance) (Hayek, 1931 pp. 27-28)[7] misrepresents of economic dynamics. This constrains the identification of the problem and its solution. The presence of "bank money" in the economy and in a financial system that is more advanced (not only banks) fundamentally changes the nature of credit. In fact, the modern financial system is characterized by financial innovation and speculation. Making credit an endogenous means for money creation was proposed by Schumpeter (1934)[1]. The underpinning questions are: "How do the economic and the financial systems interact to affect economic growth?" and, "Is there a profound difference between sociological and technological ${ }^{3}$ definitions of the financial system?" Technological

\footnotetext{
${ }^{3}$ In terms of sociological foundations of the modern financial system, the financial market was to satisfy public interest bearing the firms productivity with an easier access to financial resources. The central role of confidence in the financial system and the microbehaviour of each agent in the financial - economic system are tightly linked to the changing institutional structure of financial markets, rising complexity due to financial innovation and shadow banking and the role played by the central authorities (politics and policy) in determining financial market development. The shift from public to private self-seeking interests has created a sociological and ethical problem, highlighting that the system has perhaps developed in a remarkable technological way, but it is unbalanced to cover real social needs.
} 
development does not seem to have been combined with highly-civilized behaviour. The financial sector appears to have the power through financial innovation to spread "self-seeking" behaviour throughout the economic system, distorting the original functions for which financial institutions were established. To understand (after the 2007 - 09 crisis) the causes of "why" the presence in the economic system of the technologically advanced (but not necessarily sociologically developed) financial system could provoke the dynamics of economic expansion or depression becomes of primary importance. The main hypothesis in this study is that an economy where the financial institutions are greedy currently exists and that there is a possibility to switch from a virtuous cycle to an anticompetitive greedy cycle (bad cycle) $)^{4}$ that generates what we define a wealth trap. This latter is a type of capture of financial resources drained away from the real economic circuit to be used for speculative purposes. This concept differs from the short-term Keynesian "liquidity trap", in fact, it is a consequence of the wealth trap.

When the economy follows a so-called virtuous cycle, the presence of highly-technological financial institutions operates beneficially, with a high level of savings put into productive use in the economic system, and this spurs a highly productive level of investment and funding for innovation projects. A high level of growth results. However, the alternative perspective seems to entail new bad cycles, in which the financial state determines the growth path. As a result, the growth-finance relationship is inverted. The conflict between the public interest and private interest seems likely to be the reason for the switching between good and bad cycles.

Josef Alois Schumpeter's $(1934,1939)[1][8]$ studies make particular consideration of the role of credit. Schumpeter in his studies led over the first time of his university career put the financial system at the centre of the economic system. He argues that innovation is founded on the

\footnotetext{
${ }^{4}$ Historically, there seems to be a double cyclical path. First, the post war era, when the "virtuous cycle" represented a healthy economy with financial institutions that operated beneficially. On the other hand, after the technological revolution, a bad cycle was established (around the 70s/80s, as we will discuss later), represented by a "poor" financial state (abuse of the financial power endowed by financial innovation and an increasing capture financial resources from the real sector) that led to a lower growth path.
} 
creation of credit, and thus the importance of the financial system is crucial to facilitate the waves of innovation and, in turn, to stimulate growth. Unfortunately, he revises his analysis of finance in the second part of his university career, giving more emphasis to internal funding over the external, downplaying the role of credit creation and the bank system in facilitating innovation and economic development.

Nonetheless, he was not the only one who believed money was endogenous, and maybe he was not the first in the literature to introduce the linked concepts of swarms and clusters of innovations and endogenous money creation. Keynes'(1936)[9] ideas, like those of Schumpeter (1934), contrast with the mainstream theory claims that the diffusion of fiat money and other financial aggregates are non-neutral and cause radical structural transformations in the economic system. "Bank/Credit money" modifies the economy from a pure exchange system in which the endowment of resources are known and the main problem is the trading efficiency of the system, into a production system, in which the relevant variable is the time dimension. However, Keynes and Schumpeter had different approaches to justifying the non-neutrality concept in their monetary approach. In his General Theory (Keynes, 1936)[9] focuses its attention on the money market rather than the credit market, and it gives prominence to the stock of the value function of money. Schumpeter's analysis regards the credit market as playing a central role, and it gives importance to the means of payment function of money.

An interesting contribution was made by George Shackle, who was able to assimilate the core of Keynes's ideas about the prominent role of investment as the engine of the macroeconomy and the originator of the business cycle and growth. Shackle believed that time, uncertainty (in terms of degree of potential surprise), and expectations play a significant role in shaping the agents choices (Shackle, 1968)[10]. These three elements encapsulate Shackle's contributions to economics. He disputed the maximization of expected utility as a criterion for choice under uncertainty.

The nature of the economic phenomena provided by the use of money, where money in its full nature plays an essential role, allows simultaneous decisions to affect each other, and 
imagination (in terms of invention and not of innovation) to play the role as a means of speculation. The presence of money also implies the presence of uncertainty; in particular, if the possibility of exchanging money now for promises of money to be paid later is introduced. So-called "bank money" becomes a means of deferring decisions; decisions that are deferred cannot be anticipated and will affect future situations and events. Therefore, for Shackle, the monetary economy is inherently unpredictable.

In fact, he argued that expectations drive a "monetary economy and that expectations, although bounded by what is considered as possible (non-empty decision), cannot be predicted" (Shackle, 1967)[2]. In addition, Shackle provided some valuable insights (encapsulating the essence of the Keynesian theory of the rate of interest) into the determination of the rate of interest and its role in the macroeconomy (Chapter III of his book "Expectations, Investment, and Income"). According to Shackle (1969)[11], in the financial markets there is speculation over the interest rate. The speculation permanently, without any equilibrium position. It is an intrinsically unstable variable. Therefore, money and uncertainty are tightly linked, and uncertainty in Shackle is called "psychological potential surprise".

In this respect, Shackle points out that: “...One effect of an event which causes surprise will be to heighten at first the attractiveness of liquidity, that is, of deferment of choice of a specific blueprint, and discourage the immediate construction of equipment. If a large number of investors are thus affected by the same event, the aggregate investment-flow in some period closely following this event will be lower than it would otherwise have been.” (Shackle, 1949, p. 75)[12].

However, he does not develop a deeper analysis of the financial system impact on economic growth in his "real" business cycles, because although he accepts the endogenous nature of money and point out the non-inert role of speculation, he still considers that the rate of interest and the banking system play passive roles.

New Growth Theory (NGT) and Evolutionary Theory (ET) have a "common denominator" in Schumpeter's studies. Therefore, we might look at these two theories as sons of the same father. 
They present some important differences and similarities. NGT has developed a more impressive mathematical toolkit, but presents artifact elements with no clear link to reality (aggregate analysis); It takes into serious consideration the issues of allocation of resources and, in particular, of financial resources. However, ET has largely neglected the issues related to the allocation of financial resources and the relationship between finance and innovation; it has mainly a static approach that suffers from the lack of a solid theoretical pillar (as a consequence, evidence is often ambiguous). However, ET innovation analysis moves towards a co-evolution at micro and macro levels with heterogeneous agents. This survey aims to bring together in the analysis the NGT and ET approaches in order to lay the foundations for a new generation of economic growth model. We review these two approaches as a basis for analyzing the alternative "bad" relationship between finance and economic growth. The aim is to find the gaps and common points between NGT and ET by the comparison of two representative models in the literature. For this purpose we choose, as examples, the Aghion and Howitt model (1998)[34] and the Villemeur model (2008)[13] to define the main quantitative aspects of the two different approaches.

The remainder of the paper is organized as follows. Section 2 begins with a historical excursus on Schumpeter's views and the two sons of his theories. Section 3 reviews in detail the main qualitative aspects of New Growth Theory (NGT) and Evolutionary Theory (ET). Section 4 discusses the two representative models that describe the quantitative elements of NGT and ET and highlights evidence and the limits of the two approaches discussed. Section 5 presents evidence from the empirical literature. Section 6 explains the main hypothesis, that the economy switches from a virtuous cycle to an anticompetitive bad cycle and introduces the concept of the wealth trap. Section 7 discusses the proposed future extension of building a dynamic non-linear Agent-Based (ABM) Model which explains and shows the existence of this "double cycle". Finally, Section 8 presents the conclusion. 


\section{Schumpeter's thought and the two sons of his theories}

Economic development is a historical process of structural change. Usually, the data on production and income are used to measure this process, but it is possible to take only its elementary aspects. The issue of the finance - innovation (technological change) - growth relationship has sparked a spirited scholarly debate on growth economy. Schumpeter's analysis of the relationship between innovation and resource allocation, especially the allocation of financial resources, was central to his study of the economy. He argued that well-functioning banks spur technological innovation. The financial system (for him, in particular, the banking system) identifies and funds those entrepreneurs with the best chance of successfully implementing innovative products and production processes. In The Theory of Economic Development Schumpeter (1934)[1], argues that resources would flow around the economy, along paths described as the "circular flow of economic life". They would be fully utilized in that perpetual motion and as such will not be able to accumulate into stocks. He focuses his attention on two different but related units of analysis:

a) A microeconomic implication about the innovation activity - resource allocation relationship (with a focus on the features of entrepreneurial behaviour).

b) The macroeconomic level, where he studies the interaction between structural economic change and resource allocation.

In both levels of analysis, he pays particular attention to the role of finance in facilitating economic change.

Schumpeter (1934)[1] makes a fundamental distinction between a "monetary theory of credit" and a "credit theory of money". This latter is necessary to explain the creation of "bank money" by the credit system. In the creation of this kind of money, there is the credit essence. To obtain credit means to have money available. However, the means of payment created by the credit system does not represent an equal amount of money to put into the economic system. Credit creation does not need to be backed by an existing stock of money or goods. This creation of payment means has its centre in the banking system. 
Schumpeter claims that an entrepreneur is a typical debtor in a capitalist economy. The role of banks is not simply to operate as intermediaries between saving and credit. Usually, the credit is granted ex-ante compared to the flow of savings and the flow of goods. The bank money is defined as the independent cause of variation in prices level and productivity level of the economic system and its existence in not strictly tied to a real flow of saving. This is a specifically capitalist method to contend economic development. Therefore, a spontaneous question come up: is the capitalistic function of bank money the problem that needs to be solved?

For reply to this question, we need to understand what exactly is capital. Schumpeter (1934)[1]defines it as the sum of the means of payment in the hands of private individuals. Capital does not have a real nature; it is a stock of purchasing power. The capital required by entrepreneurs detaches resource from the circular flow to undertake new combinations that may also be generated ex nihilo. Schumpeter $(1934,1939)$ [1][8] believed that credit could be created in a variety of ways, but he gave prominence to the role of commercial banks in generating new purchasing power and making it available to entrepreneurs. The challenge for Schumpeter was to explain how the financial system (in particular the banking system and its credit expansion and contraction) facilitates the reallocation of economic resources, changing (or sometimes manipulating dramatically) the structure of the economy. He argued that the evolution of a country's financial system was of crucial importance for facilitating the waves of innovation that he regarded as the "motive force" behind its economic development $(\mathrm{O}$ ' Sullivan, 2004)[14].

Schumpeter $(1939,1942)[8][15]$ revised his analysis of resource allocation in a dynamic economy and, in particular, his analysis of finance. He downplays the role of credit creation and the banking system in facilitating innovation and economic development in favour of an emphasis on internal finance for facilitating innovative investment. Previously he had given prominence to the role of commercial banks in generating new purchasing power and to their capability of making it available to entrepreneurs, considering firms as single units (with 
innovation dominated by new human resources and firms). In this contest, the banker makes possible the funding of the new entrepreneurs plans to implement new combinations. Schumpeter altered his characterization of innovation, looking at technological progress as the business, not of individual entrepreneurs, but as a "perfectly bureaucratized giant industrial unit". This large-scale enterprise becomes "the most powerful engine" of economic progress by rationalizing and routinizing the process. With this view, internal funding becomes predominant.

The Economists have adopted different frameworks for the analysis of the relationship between economic growth, finance and innovation. An important current debate emerged during the 1980s and 1990s between "evolutionary theory" (ET) and the more neoclassically inspired "new growth theory" (NGT). We consider them as the "two sons of Schumpeter". This analogy highlights the shared thoughts of Schumpeter that have inspired both. The gap between these two approaches is rooted in the fundamental differences in their basic views. While the neoclassical tradition adheres to a worldview in which cause and effect are clearly separable, and growth is an ordered, steady-state phenomenon, the evolutionary worldview is one of historical circumstances, complex casual mechanisms that change over time, and, above all, turbulent growth patterns that appear to be in far from a steady state (Verspagen, 2004)[16].

Neoclassical aggregate models of exogenous and endogenous growth in equilibrium dominate the analysis of economic growth in the literature, where important contributions are made by Romer (1986, 1990)[17][18] and Aghion and Howitt (1998) [34]. Although they have generated many clear insights, they suffer from two main problems:

a) Certain significant elements linked to growth are not considered in their description of reality. Economic growth rarely occurs without structural change.

b) Many assumptions are convenient but erroneous as representative agents, rational behaviour, perfect information, aggregate function and growth in equilibrium.

\footnotetext{
${ }^{5}$ It represents an important distinction between the older and present new growth theory views.
} 
Instead, the evolutionary approach is characterized by the interaction of innovation and selection; the changing populations of heterogeneous agents; the impact of economic distribution on economic dynamics; and agents characterized by adaptive routines and imitation. Since the 1980s, growth has been studied from the perspective of evolutionary theories of growth and technical change (van den Bergh, 2004)[19].

In general, the two approaches differ less in their views of the importance of innovation and technology for growth. However, other elements, in particular the role of the financial system in stimulating the innovation process, differ more. In fact, the NGTs consider the role of financing factors and financing intermediaries as endogenous. This is because the NGTs are inspired by Schumpeter's studies made in the first part of his academic career. Conversely, the ETs have largely neglected the relationship between finance and innovation, as they are inspired by Schumpeter's thoughts from the second part of his studies, when himself neglected the important role of the financial system. Therefore, they disagree on the behavioural foundations underlying the respective theories (Verspagen, 2004)[16].

The above discussion emphasizes the importance of a thorough analysis of the relationship between finance and growth. The recent chain of events (the 2007/2009 financial crisis and its economic consequences) has reopened an interesting debate on the new perspective, in which the financial role defines the growth path; the vision contrasts with (or better, is alongside of) the traditional one, according to which finance follows growth. For a better understanding, it is useful to start with an overview of the NGT and ET approaches. The following section presents the main assumptions and insights of ET and NGT theories for the analysis of economic growth, innovation and finance aspects. The main similarities and differences are briefly discussed.

\subsection{NGT and ET: main contributions}

NGT overtakes the unresolved issues into the neoclassical mainstream model of economic growth (the Solow model, 1956)[20]. For NGT, innovation is the main resource for growth. We can identify the main NGT development in: 
a) The first generation (Lucas, 1988; Romer, 1986)[21][17], in which a positive growth rate in the long-run period can be explained by an endogenous technological progress. An important element of these models is the technological change at decreasing returns of scale in the aggregate production function ${ }^{6}$.

b) The second generation (Romer, 1990; Grossman and Helpman, 1990)[18][22], who introduce the concept of public goods (partly appropriable) ${ }^{7}$, and innovation created by a separate R\&D sector. The economy takes the form of an increasing "variety" of intermediate goods with monopolistic competition (not perfect competition).

c) The third generation (Grossman and Helpman, 1991; Aghion and Howitt, 1992)[23][3], for whom the uncertainty aspect is connected to innovation activity as a "computable risk". They tend to highlight that a technological competition process and economic growth exist, characterized by Schumpeterian "creative destruction". Monopolistic power is, therefore, temporary.

d) The recent generation, the General purpose technologies (GPT)(Helpman, 1998)[24], in which two ideas from the evolutionary tradition are captured: the idea of differences in innovation size, and the idea that incremental innovations are responsible for the diffusion of a basic technology. The GPT model generates cyclical growth and resembles the evolutionary, Schumpeterian idea of long waves in economic growth.

In this context, Aghion and Howitt's (1998)[34] contribution is important, drawing the line of distinction between the older and present views of endogenous growth theory.

On the other hand, the starting point of the evolutionary tradition is the Nelson and Winter (1982)[4] model, in which heterogeneity is defined in terms of firms which use production techniques that employ a fixed ratio of labour and capital. Nelson and Winter developed the first formal evolutionary model of economic growth, which is compared with Solow's famous descriptive growth model from 1956 [20]. The three building blocks of Nelson and Winter's theory of microevolution are: 1) organization routines; 2) search behaviour; and 3) selection

\footnotetext{
${ }^{6}$ This can cause, as shown by the empirical evidence, persistent differences in growth rates among countries.

${ }^{7}$ Entrepreneurs can appropriate part of the technological progress results in form of the monopolistic rents.
} 
environment. Historical analysis often is used by evolutionary scholars to develop heuristic patterns that can be used to describe and categorize these developments in a more general way. Nelson and Winter's purpose is to generate and explain patterns of aggregate outputs, inputs and factor prices. Based on their search results, they argue that although both the neoclassical explanation of economic growth offered by Solow, and their model seem to explain the same empirical trends, the casual mechanisms underlying the two perspectives differ greatly. In the evolutionary literature, much has been made of the concepts of the technological paradigm $\left(\right.$ Dosi, 1982) ${ }^{8}[25]$ and natural trajectories (Nelson and Winter, 1982)[4]. The paradigm limits the possible directions that technological development may take. There is some room for choice within the paradigm, and the specific circumstances govern these choices (e.g. the scarcity of a particular resource) in which the technology develops. This development is termed a “technological trajectory". Evolutionary models which follow Nelson and Winter (1982)[4] include Silverberg et al. (1988)[26], Conlisk (1989)[27], Chiaramonte and Dosi (1993)[28] and Silverberg and Verspagen (1998)[29]. Colinsk (1989)[27] presented one of the rare models in this tradition that is solved analytically rather than by numerical simulation. The growth rate can be analytically derived as being dependent on the rate of diffusion of innovations and their size, as indicated by the standard error of the productivity probability distribution. Silverberg et al. (1988) [26] proposed an evolutionary growth model that starts from the Goodwin (1967)[30] model. In their model, an important behaviour rule is that new capital follows from profit accumulation, where profit is redistributed, so that relatively profitable types of capital accumulate relatively quickly. This can be regarded as selection, in that a technique with relatively high fitness spreads quickly, combined with a growing "population of technologies" through accumulation. Firms can employ two strategies for innovation: mutation or imitation. The probability of imitation depends on the gap between the firms' profit rate and the maximum profit rate in the population. Chiaramonte and Dosi (1993)[28] show how growth rates in a cross-section of nations may differ, while Silverberg and Verspagen (1998)[29] demonstrate

\footnotetext{
${ }^{8}$ Dosi (1982)[25] defines a technological paradigm "as "model" and a "pattern" of solution of selected technological problems based on selected principles derived from natural sciences and on selected material technologies." (pp. 152)
} 
how "routines" of R\&D investment may arise endogenously in a population of firms, and how growth patterns vary with the history of an economy that learns in such a "collective" way.

Another set of heuristics developed in the historical part of evolutionary economics relates to the temporal clustering of innovations. The recent so-called "history-friendly models" (Malerba et al. 1999) [31] aim to bring the evolutionary models closer to empirical reality by reproducing the historical evolution of a particular industry. In this view, some historical periods are characterized by an above average rate of "basic" innovations while other periods show a relatively low rate of such activity. Together, these two sets of heuristics have interesting implications for growth. They suggest that technological innovation can introduce an uneven temporal pattern into economic growth. One extreme interpretation of this temporal pattern of innovation is the idea of a "long wave" in economic growth, in which periodicity is bounded in a short range of 50-60 years. Another view claims that growth patterns are inherently turbulent, but with little regularity in terms of strict cycles. Theories and historical analyses of this type propose a view of the interactions between technology, the economy and the institutional context. The institutional environment is important because it is a facilitator of and an impediment to technological change and, consequently, to economic growth.

Among the most important recent proposals concerning the direction evolutionary economics should follow is without doubt that of Potts (2000)[32]. Potts presents a kind of axiomatic foundation of evolutionary economics. In his view, economic systems are complex "hyperstructures", i.e. nested sets of connections among components. Economic change and growth of knowledge are, in essence, a process of changes in connections. Firm and economic growth are a process of creation of more complex organization or new connections, as well as the grouping of those connections.

Finally, another interesting view is taken by the neo-Schumpeterian theories of technical change which currently dominate the evolutionary approach in economics (Dosi et al., 1988; Metcalfe, 1998)[33][66]. They believe innovation causes asymmetry in technology between firms, sectors and countries, leading to exchange and trade. Comparative advantages are not fixed, but change 
due to innovation and diffusion. Trade itself stimulates diffusion of knowledge. In addition, technological change affects the division of labour, the organization of intra-firm and inter-firm relationships, and thus the industrial structure and patterns of intermediate deliveries. Within the neo-Schumpeterian literature on technological evolution, the notion of path dependence has received much attention. This is a result of increasing returns, which may be due to learning by using; bandwagon demand side effects (imitation); network externalities; informational increasing returns (if more adopted, then better known); and technological interrelatedness or complementarily. A consequence of increasing returns or path dependence on one of the multiple potential equilibriums, is that inefficient equilibrium can arise, and a certain (inefficient) technology can become locked-in (van den Bergh 2004)[19].

\section{NGT and ET: a qualitative comparison}

By comparing the two theories, it is possible to establish the main qualitative and quantitative similarities and differences. This section focuses on the main qualitative elements that distinguish the two different approaches (see Table 1).

NGT defines R\&D at the aggregate level. It explicitly shows growth fuelled by technical changes $^{9}$ and that these changes are made endogenous by the outlays on $\mathrm{R} \& \mathrm{D}$, as a variable core. Representative or identical agents with individual rationality (marginal decision rules), which maximize the utility functions, are assumed. Social (intertemporally) optimization explains the neoclassical growth theory focus on the equilibrium growth paths.

This theory considers uncertainty and irreversibility. However, it is characterized by weak uncertainty; i.e. firms can estimate the probability of obtaining the innovation-price, given the level of $R \& D$ spending. Firms may make a cost-benefit analysis and define an optimal level of $R \& D$ spending, given the benefits and costs of $R \& D$ expectation. This corresponds to the average of a given amount of innovation and produces a given growth rate. Although additional assumptions are necessary (e.g. about capital market operativity in which R\&D expenditures

${ }^{9}$ NGT and ET share the importance attached to the technology factor. 
have to be financed), this mechanism is the key to generating endogenous growth. NGTs include the notion that R\&D and technology are essentially stochastic phenomena and the importance of technology flows between agents (spillovers) for growth in the long-run.

This approach focuses attention on public externalities in technological innovation through the public good nature of certain aspects of knowledge and technology. The assumption takes two forms, depending on which flavour of the model is used. In the "horizontal differentiation" type of models ${ }^{10}$ (i.e. the models by Romer, 1990)[18], each innovation increases the level of general knowledge available in the economy, and this increases the productivity of the R\&D process. In the "vertical differentiation" types of models ${ }^{11}$ (i.e. models by Aghion and Howit, 1992)[3], each new innovation destroys the monopoly of the old innovator (Schumpeterian creative destruction). However, the new innovator builds on previous innovation because the quality of the new capital good is a fixed increment over the previous one. In other words, there is intertemporal knowledge spillover from one innovator to the next.

Therefore, the new notion is growth as a deterministic and predictable process in which causality is clear-cut, and policies can be built on the time-invariant determinants of growth patterns.

Only more recently has the endogenous growth literature suggested that financial intermediation has a positive effect on steady-state growth (see Pagano, 1993)[35] and that government intervention in the financial system has a negative effect on the equilibrium growth rate (King and Levine, 1993) ${ }^{12}[36]$. NGT incorporates the role of financial factors, with financial intermediation considered as an endogenous process. There may be a two-way causal relationship between financial intermediation and growth:

\footnotetext{
${ }^{10}$ In this model, there is competition between new and old varieties and substitution between variations of goods is governed by a utility function or production function, with a "constant elasticity of substitution".

${ }^{11}$ The innovation process is modeled as a "quality ladder" of innovation, in which each new innovation supersedes the old one.

${ }^{12}$ E.g., increasing taxes on financial intermediaries is seen as equivalent to taxes on innovative activity, which lowers the equilibrium growth rate. Imposing credit ceilings reduces individual incentives to invest in innovative activity, which slows the growth of the economy (King and Levine, 1993b) [36].
} 
1. The growth process encourages higher participation in the financial markets, thereby facilitating the establishment and promotion of financial intermediaries ${ }^{13}$.

2. Financial development can affect growth not only by raising the saving rate but also by raising the amount of saving funneled to investment and/or raising the social marginal productivity of capital.

These developments contrast with the previous thesis put forward by Modigliani and Miller (1958)[6] that look at the financial markets as independent entities from the rest of the economy (i.e. finance and growth are unrelated). However, some economists still would argue that finance and growth are unrelated ${ }^{14}$.

ET derives production as well as technical change from the population of firms (the population approach); it aims at co-evolution by micro and macro levels of analysis. The Evolutionary theorists explicitly address the notion that growth is fueled by technical change with the R\&D variable. Technical change $(R \& D)$ is made endogenous by the outlays on $R \& D$, as a variable core (the same as NGT).

From the philosophical view, evolution is supported by opposite forces or casual processes: the creation or generation of variation and the selection or reduction of variety. The evolutionary model can address behavioural and technical diversity or heterogeneity. Over time, the variety present in the system is reduced by selection. Novelty is constantly added to the system, and therefore evolution is the outcome of a constant interaction between variety and selection. Innovation is an important novelty-generating process, and the market and other economic institution are among the most important selection mechanisms in modern economies. It assumes, in contrast to NGT, that decision makers operate under a scheme of bounded rationality, usually in the form of routines and learning through imitation (individuals and organizations behave automatically according to adapted or selected habits and routines; they imitate others and are myopic). There are no fixed increments of variety or novelty, but they can

\footnotetext{
${ }^{13}$ This enables a more efficient allocation of funds for investment projects, which promotes investment itself and enhances growth (Greenwood and Jovanovic, 1990)[37].

${ }^{14}$ A good example of this view is that of Lucas (1988)[21], who argues that economists "badly over-stress" the role of the financial system, thereby reinforcing the difficulties of agreeing on the link and its direction between finance and growth.
} 
be changed over time, especially so under the influence of feedback on economic performance, which explains the evolutionary approach's focus on non-equilibrium. ET models can generate patterns quite close to those generated by neoclassical models, with a particular technological change assumption (as illustrated by Nelson and Winter, 1982 and Colinsk, 1989)[4][27]. ET also shows uncertainty and irreversibility concepts (as in NGT, but here is more common). In particular, the crucial assumption is that the outcomes of the $R \& D$ process can be realistically characterized by strong uncertainty. The nature of the growth process is more complex and variable over time. ET theorists believe in a "never ending" and "ever chancing" process. ET is particularly suited to the analysis of historical processes, in which contingencies and specific historical circumstances play a larger role. The casual mechanisms that prevail in one period may be subject to endogenous change in the next. An important implication of evolutionary change is that a system that has so much diversity is extremely unlikely to return to a previous state. In economics, this is known as path dependence. In this world (with non-deterministic and unpredictable processes), designing policy is harder, but not impossible. Indeed, a unique and important feature of evolutionary thinking is that it can integrate theory and history:

"While the importance attached to the technology factor is shared with the new growth models, the belief that the relation between technology and growth is easily tweaked is not. In the evolutionary view, it is hard to predict exactly the impact of a policy measure because it impacts on a complex range of interrelated factors. Moreover, while relations between a number of factors may have been revealed by careful research for a specific instance in time, it is to be expected that the nature of this relationship will change over time, exactly because of the (co)evolutionary nature of the process." (Verspagen, 2004)[16].

Evolutionary theorists largely base their analysis on Schumpeter's studies conducted in the second part of his academic career (when he downplayed the role of credit creation in 
facilitating innovation and economic development); therefore, they, like many contemporary economists of innovation, have largely neglected the issues related to the allocation of financial resources and the relationship between finance and innovation. The evolutionary approach pays little attention to institutional structures to fund and promote innovation (this is a large gap). Carlota Perez (2002)[38] is a very interesting recent contribution in her book Technological Revolutions and Financial Capital: The Dynamics of Bubbles and Golden Ages, in which the relationship between finance and techno-economic paradigms receives systematic treatment. She argues that the relationship between the financial and productive sectors changes as the economy moves from one stage of the life cycle to another. However, this original contribution suffers from certain limitations; in particular, systematic empirical support for some of the key arguments that she makes about the role of finance in funding technological revolutions is not provided.

\subsection{NGT and ET: main unresolved issues}

On one hand, a crucial concept in NGT is the aggregate production function. Of course, neither single firms nor the aggregate of all firms can move along an aggregate and continuous production function because they only possess information or knowledge about a limited and discrete number of production techniques. This assumption, accepted by a large part of the literature, is considered an artifact with no clear link to reality. Instead, evolutionary theories propose the avoidance of an aggregate production function and instead describe the diversity of production relationships at the level of individual firms.

On the other hand, evolutionary theorists have largely neglected the issues related to the allocation of financial resources and the relationship between finance and innovation, and, therefore, the effect on the growth. Consequently, evolutionary economists need to develop an explicit analysis of the implications of questions about resource allocation (in particular financial resources) as characteristics of innovation at the level of the enterprise, the industry and the economy (in economic growth terms). 
Table 1 - Comparison between New Growth Theory and the Evolutionary Approach.

\begin{tabular}{|l|l|}
\hline New Growth Theory & Evolutionary approach \\
\hline $\begin{array}{l}\text { Aggregate production function based on the } \\
\text { neoclassical micro foundation }\end{array}$ & $\begin{array}{l}\text { Reflects the analysis of the micro-level (starting } \\
\text { from a population of firms); toward a co-evolution }\end{array}$ \\
\hline
\end{tabular}




\begin{tabular}{|c|c|}
\hline Representative agent & Heterogeneous agents \\
\hline Agents make their decisions independently & $\begin{array}{l}\text { Economic agents are interrelated and coordinated } \\
\text { with each other }\end{array}$ \\
\hline Individual rationality & Bounded rationality \\
\hline Endogenous R \& D & Endogenous R \& D \\
\hline Defines R \& D at the aggregate level & $\begin{array}{l}\mathrm{R} \& \mathrm{D} \text { is explicitly assumed to be within the } \\
\text { productive enterprises }\end{array}$ \\
\hline Focus on innovation externalities & $\begin{array}{l}\text { Focus on barriers and delays to diffusion of } \\
\text { innovation }\end{array}$ \\
\hline $\begin{array}{l}\text { Weak uncertainty, risk computable, stochastic } \\
\text { process predictable. Irreversibility }\end{array}$ & $\begin{array}{l}\text { Strong uncertainty: non-deterministic and } \\
\text { unpredictable process. Irreversibility }\end{array}$ \\
\hline Toward the steady state & "Never ending" and "ever changing" \\
\hline $\begin{array}{l}\text { Does not take into account the structural changes } \\
\text { underlying growth }\end{array}$ & $\begin{array}{l}\text { Takes into account the structural changes underlying } \\
\text { growth }\end{array}$ \\
\hline There is a common agreement on the approach & There is no common agreement on the approach \\
\hline $\begin{array}{l}\text { Incorporates the role of financial factors (financial } \\
\text { intermediation as an endogenous process) }\end{array}$ & $\begin{array}{l}\text { Largely neglects the issues related to the allocation } \\
\text { of financial resources }\end{array}$ \\
\hline
\end{tabular}

\section{NGT and ET: two representative models to explain the}

\section{main quantitative aspects}

The goal to survey these two different approaches (but linked to the thoughts of Schumpeter) is the basis for the analysis of the reverse relationship between economic growth and finance. The aim is to find the gaps in the literature and the common points. As examples, we review briefly the Aghion and Howitt (1998)[34] and the Villemeur (2008)[13] models in order to define the main quantitative aspects of the two different approaches, making a distinction between: 
a) The Schumpeterian-Neoclassic Endogenous Growth approach: Aghion and Howitt, 1998

b) The Schumpeterian-Evolutionary Growth approach: Villemeur, 2008

a) Aghion and Howitt (1998)[34] in their book Endogenous Growth Theory (see chapter 2) show the Schumpeterian-neoclassic endogenous approach.

They develop a model in which growth is generated by a random sequence of quality improving (or vertical) innovations that themselves result from uncertain research activities. This model considers the concept that new inventions make old technologies or products obsolete (following the Schumpeterian view), i.e. so-called "creative destruction". This replacement happens by raising the technology parameter $\mathrm{A}$ by the constant factor $\gamma>1$ (so-called innovation size). Innovations consist of the invention of a new variety of intermediate goods. The output of consumption goods depends on the input of an intermediate good, $x$, according to: $y=A x^{\alpha}$ where $0<\alpha<1$

Aghion and Howitt also describe a "capital intensive economy" with multisectors in which more innovation stimulates capital accumulation by raising the marginal product of capital; more capital accumulation stimulates innovation by raising the profits accruing to a successful innovator (see Aghion and Howitt, 1998, chapter 3)[34]. For them, capital plays an important role as an input to research and it determines the path level of growth in the long run.

The economy is populated by a continuous mass L of individuals with linear intertemporal preferences

$u(y)=\int_{0}^{\infty} y_{\tau} e^{-r \tau} d \tau$

where $y$ denotes the output of the final good and $r$ is the rate of time preference (interest rate). Society's fixed stock of labour can produce intermediate goods, and it can be used in research: $L=x+n$ 
where $x$ is the amount of labour used in manufacturing and $n$ is the amount used in the research sector. When the amount $n$ is used in research, innovation arrives randomly with a Poisson arrival rate $\lambda n$, where $\lambda>0$ is a parameter indicating the productivity of the research technology. The amount of labour involved in research is determined by the arbitrage condition, when the objective of a firm is to maximize the flow of expected profit from research:

$$
\begin{gathered}
\lambda n_{t} V_{t+1}=n_{t} w_{t} \\
w_{t}=\lambda V_{t+1}
\end{gathered}
$$

where $t$ is the number of innovations that have occurred so far, $w_{t}$ is the wage and $\lambda$ is the flow probability of an innovation times the value $V_{t+1}$ that it is the discounted expected payoff to the $(t+1)^{t h}$ innovation. If $w_{t}$ defines the value of an hour in manufacturing, $\lambda n_{t+1}$ is the expected value of an hour in research. The value $V_{t+1}$ is the expected present value of the flow of monopoly profits generated by the $(t+1)^{t h}$ innovation, given the internal human resources involved in the research sector, whose length is exponentially distributed with parameter

$$
\begin{aligned}
& \lambda n_{t+1}\left(1 / \lambda n_{t+1}\right)=\text { waiting _time } \\
& V_{t+1}=\frac{\pi_{t+1}}{r+\lambda n_{t+1}}
\end{aligned}
$$

The denominator is the obsolescence-adjusted interest rate and shows the effect of creative destruction. This arbitrage equation governs the dynamics of the economy over its successive innovations. Together with the labour market equation, it constitutes the backbone of the basic Schumpeterian model. The expected income (in the individual rationality perspective) generated by a new license on innovation is equal to the profit flow attainable by the $(t+1)$ intermediate good monopolist minus the expected "capital loss" that will occur when the $(t+1)^{t h}$ innovator is replaced by a new innovator. 
Therefore, the model is fully characterized by both the arbitrage equation and the labour market clearing equation. The arbitrage equation reflects that labour can be freely allocated between manufacturing and research

$$
\begin{aligned}
& \frac{w_{t}}{A_{t}}=\lambda \frac{\pi_{t+1}}{r+\lambda n_{t+1}} \frac{1}{A_{t}}=\lambda \frac{\tilde{\pi}\left(w_{t+1}\right)}{r+\lambda n_{t+1}} \frac{A_{t+1}}{A_{t}} \\
& w_{t}=\lambda \frac{\gamma \tilde{\pi}\left(w_{t+1}\right)}{r+\lambda n_{t+1}}
\end{aligned}
$$

The labour market clearing equation reflects the frictionless nature of the labour market and determines the growth-adjusted wage rate

$$
L_{t}=n_{t}+\tilde{x}\left(w_{t}\right) \quad \text { if } \quad w_{t}<\lambda V_{t+1}
$$

Therefore, it pays to increase $n_{t}$. Given the labour market clearing equation above, this means that $x_{t}$ decreases, which implies that $w_{t}$ must increase.

Consequently, $\lambda n_{t+1}$ will be the probability of the innovator losing his monopoly rents. In the model the profit flow $\pi_{t}$ and also the flow demand for manufacturing labour $x_{t}$, both are determined by the same profit-maximization problem solved by the intermediate producer that used the $t^{\text {th }}$ innovator. The monopolist chooses the level of output $x$ that maximizes his profits:

$$
\pi_{t}=\max _{x}\left[p_{t}(x) x-w_{t} x\right]
$$

where $w_{t}$ is the wage and $p_{t}(x)=A_{t} \alpha x^{\alpha-1}$ is the price at which the $t^{\text {th }}$ innovator (or intermediate firm) can sell the flow $x$ of intermediate input to the final good sector; $t^{\text {th }}$ is able to extract the whole expected net present value of (monopoly) profit generated by that innovation.

$$
\begin{aligned}
& \pi_{t}=\arg \max _{x}\left[A_{t} \alpha x^{\alpha}-w_{t} x\right]=\left(\frac{\alpha^{2}}{\frac{w_{t}}{A_{t}}}\right)^{\frac{1}{(1-\alpha)}} \equiv\left(\frac{w_{t}}{A_{t}}\right) \\
& \left(\frac{w_{t}}{A_{t}}\right)=\omega_{t} \text { (productivity-adjusted wage) }
\end{aligned}
$$


The equation above expresses $x$ as a decreasing function of $\omega_{t}$ and substitutes for $x$ in the profits function:

$$
\pi_{t}=A_{t} \alpha x^{\alpha}-w_{t} x=\left(\frac{1}{\alpha}-1\right) w_{t} x=A_{t} \tilde{\pi}\left(\frac{w_{t}}{A_{t}}\right)=A_{t} \tilde{\pi}\left(\omega_{t}\right)
$$

Here is assumed that the final good sector is competitive. This introduces an additional reason, besides creative destruction, for the negative dependency of current research on the amount of expected future research. Specially, a higher demand for future research labour will push future wages up, thereby decreasing the flow of profit to be appropriated by the next innovator. This, in turn, will tend to discourage current research; that is, to drive $n_{t}$ down.

A steady-state equilibrium is simply defined as a stationary solution to the system. Both the allocation of labour between research and manufacturing and the productivity-adjusted wage rate (for which the demand for manufacturing labour is a decreasing function) remain constant over time, so that wages, profit, and final output are all scaled up by the same $\gamma>1$ each time a new innovation occurs.

An important aspect that appears in the Aghion and Howitt (1998)[34] book is the relationship between growth and finance. This relationship starts gaining substance when the concept of capital-market imperfections is introduced. King and Levine (1993)[36] extend the basic framework by introducing an agency cost of determining the time value of a research project. With ex-ante probability $\phi$, a research project is relevant and can then generate an innovation with flow probability $\lambda$. With probability $(1-\phi)$, the research project generates no value at all. If $f$ denotes the flow cost (in labour units) incurred by the financial intermediary to discover the true type of each research project, then the intermediary will require a flow repayment equal to $f / \phi$ for a successful project to break even. In particular, the larger the agency cost, the lower the equilibrium level of research and, therefore, the lower the growth rate. However, the more developed (or more advanced) financial systems and the lower intermediation costs (as a result 
of scale economies) generate the faster rate of economic growth. Evidence from the ratio of liquid liabilities of the financial system to GDP (or from the ratio of commercial bank to central bank credit) and growth is provided by King and Levine (1993) [36]. The introduction of taxes on the financial sector will discourage research and growth by increasing the break-even cost of financial intermediation: $f / \phi(1-\tau)$ (where $\tau$ is the tax rate on financial revenues). Other arguments (in particular in the financial literature) concentrate on monitoring costs, in particular by intermediate firms when adopting new technologies, and the role of financial intermediaries in reducing individual monitoring costs; the stock market might equally well perform the monitoring of research projects. On one hand, growth will be slow and risky at the early stage of development (few individuals investigate in high-yield projects, and their aggregate risk is high). On the other hand, when growth will accelerate the volatile is reduced and at the later stages of development a large number of risky projects can be simultaneously undertaken and monitored by the financial sector.

b) The Alain Villemeur (2008)[13] model, published by the 12th International Schumpeter Society Conference in Rio de Janeiro, shows the Schumpeterian - evolutionary growth approach.

Economic growth is seen as the outcome of an entrepreneur-driven process of evolution in the context of an economy of competitive markets and free-market economy. In the economic evolutive process, entrepreneurs implement capital and labour factors; this is a sequential evolution. Therefore, we will have a sequence of decisions that the entrepreneur makes in the period $(t, t+d t)$. Growth is the result of an evolutionary process during which firms implement new productive combinations spurred by innovation, with capital and labour inputs being in part substitutable and in part complementary, with increasing returns to scale. Capital is thus substituted for labour over vintage capital (from Schumpeter, 1934 "produce differently")[1], while capital can give rise to increasing returns through the implantation of extra machines (from Schumpeter, 1934 "produce more")[1]; substitution and complementarity are the two 
faces of "creative destruction". The conditions for equilibrium in the labour market are that entrepreneurs aim to implement productive combinations in which wage gains are independent of the employment growth rate $\frac{\dot{w}}{w}$ independent $\frac{\dot{L}}{L}$

This assumes additional production linked to a new productive combination using the technique $A$, i.e. so-called "technical productivity". By installing additional production, entrepreneurs make complementary use of capital and labour to create extra output (to "produce more"). Parameter $A$ is presumed to be constant over a long period and common to all entrepreneurs, since, by definition, substitution occurs in continuous production (to "produce differently").

The technique is assumed to be a putty-putty model, given the perfect substitutability of the inputs (as in the Solow model, 1956)[20]; the proportion of factors is not fixed, because of the existence of numerous possible technical combinations. We can write the additional production equation as: $\dot{Y}=A x \dot{K}$ with $A>0,0 \leq x \leq 1$

where $\dot{K}$ is the variable volume of capital necessary to plan additional output, and $x$ is the "complementary rate", i.e. the share of the increment of capital engaged in "producing more". Entrepreneurs make successive investments, production and employment decisions, considering consumer demands and formulating expectations for the ensuing periods. During the process, remuneration is paid to employees, and entrepreneurs' decisions and the productive combinations depend on the price of factors. Thus, income distribution is the core of firms' investment decisions. Therefore, we assume that production meets demand and the balance between investment rate $(i)$ and saving rate $(s)$ is achieved and investment is assumed to be equal to saving ( $i=s$ ); they will be called the "rate of accumulation". It is possible to deduce that the output growth rate is proportional to technical productivity, the complementary rate and the rate of accumulation. In other words, production-demand balance is achieved throughout the sequence of decisions. To simplify, the model also accepts that the prices of goods are fixed in each period. 


$$
\begin{aligned}
& \frac{\dot{Y}}{Y}=A x \frac{\dot{K}}{Y}=A x i=A x s \quad \text { with } \dot{K}=I \\
& \frac{I}{Y}=i=s \\
& Y=C+I
\end{aligned}
$$

Accounting for innovations, the Villemeur model assumes that the marginal rate of labour productivity $\left(\dot{Y} / L_{c}\right)$ is higher than labour productivity, the coefficient of proportionality (as measure of elasticity) $e_{c}$ is suppose variable and $\varepsilon_{c}$ is the "job creation coefficient".

$$
\frac{\dot{Y}}{Y}=e_{c} \frac{Y}{L} \quad \text { with } \quad e_{c}>1 \Rightarrow \quad \frac{L_{c}}{L}=\frac{A}{e_{c}} x s=\varepsilon_{c} x s \quad \text { with } \quad \varepsilon_{c}=\frac{A}{e_{c}}, \quad 0<\varepsilon_{c}<A
$$

Returns to scale are increasing and translated by a coefficient higher than the unit. The employment growth rate is the result of the balance between the job creation rate and the job loss rate, but where a maximal coefficient of job creation exists $\left(\varepsilon_{c}^{m x}\right)$.

$$
\varepsilon_{c}+\varepsilon_{l}=\varepsilon_{c}^{m x} \text { with } 0<\varepsilon_{c} \leq \varepsilon_{c}^{m x}, 0 \leq \varepsilon_{l}<\varepsilon_{c}^{m x}
$$

where $\frac{L_{l}}{L}=\varepsilon_{l}(1-x) s$ with $\varepsilon_{l} \geq 0$

Consequently, the constraint of labour organization imposes limits on creating or cutting jobs. We can say that the employment growth rate depends on the rate of accumulation, the complementary rate, the job creation coefficient, and a parameter reflecting the organizational limit to creating or cutting jobs. 
$\frac{L}{L}=\varepsilon_{c}^{m x} x s-\left(\varepsilon_{c}^{m x}-\varepsilon_{c}\right) s$ with $0<\varepsilon_{c} \leq \varepsilon_{c}^{m x}$ and $A>\varepsilon_{c}^{m x}$

Given the competition in the goods market framework, entrepreneurs will aim for competitiveness through their investments throughout the sequence. One condition for equilibrium is that entrepreneurs adopt productive combinations that minimize the unit production cost (per investment unit) related to the investment made, while taking into account the return on capital expected (in the bounded rationality perspective) by the financial market ${ }^{15}$ (Robinson, 1954)[39]. The cost of production $C_{m}$ per investment unit is written

$C_{m}=w \dot{L}+z_{a} \dot{K}$

with $z_{a}$ expected return on capital. The model assumes that the entrepreneur minimises the cost per investment unit under two particular constraints: a) the share of profit $c$ in income is constant in order to maintain the share of profit when choosing new combinations; b) the cost of job creations $\varepsilon_{c}$ for output, per investment unit, is inversely proportional to the expected return on capital.

This latter constraint reflects that the greater the expected return on capital, the fewer jobs will be created, given the risks taken by the entrepreneurs who create jobs to produce goods.

The entrepreneurs, at each time $t$, use the following minimization program:

$\operatorname{Min}\left\{\frac{C_{m}}{\dot{K}}\right\}$, subject to: $c=c_{1}, \quad x \varepsilon_{c} z_{a}=c_{2}^{\prime}$

The condition for a solution requires that expected return on capital must be below a level that depends on the technique employed and the share of profits in income.

${ }^{15}$ The return expected by an entrepreneur is assumed to be a function of financial market requirements. 
$z_{a} \leq(1-c) \varepsilon_{c}^{m x}$

In the financial market framework, the condition for equilibrium imposes an expected return on capital equal to return on capital in $z_{e}$. The Villemeur model also assumes that in the long-term, the return on capital is a time constant, while entrepreneurs aim to keep the profit share in income constant (neutrality for technical progress):

$$
z_{a}=z=z_{e}=\text { constant }, \quad c=\text { constant }, \quad \text { with } \quad z=c \frac{Y}{K}
$$

The condition for market equilibrium only depends on the return on capital at equilibrium. The determinants of long-term growth are thus employment growth, the rate of accumulation and technical productivity (marginal). In this model growth path, appear in disequilibrium due to competitiveness. Economic growth thus appears to be processes in continuing disequilibrium characterized by an attractor, in which the paths of growth in a way curl themselves around this attractor, without ever durably reaching it.

\subsection{Main similarities and differences}

The evolutionary and the neo-classical traditions have converged somewhat in the phenomena deemed central within each analytic approach. In this subsection briefly illustrates the main similarities and differences between the models proposed (Aghion and Howitt, 1998; Villemeur, 2008)[34][13] and is closely linked to the qualitative review made in section 3. It is immediately possible to note the difference between the representative agent (the firm in the neoclassical view) and the heterogeneous agent (the entrepreneur in the evolutionary view). The main common points between both models are the competitive market of the final good sector and a sequence of evolution (vertical differentiation; for NGT, the sequence of evolution is characterized by the invention of a new variety of intermediate goods by intermediate firms, 
while for ET it is a sequence of decisions that the entrepreneurs make). In addition, there is uncertainty over the productivity results (but for ET this is more common) and the Schumpeterian concept of obsolescence ("creative destruction"). Finally, parameter $A$ is constant and endogenous in the economic system.

The main differences between the neoclassical and evolutionary frameworks are that the neoclassical works present profit-maximizing firms, ${ }^{16}$ with an economy populated by a continuous mass $L$ of individuals with linear intertemporal preferences (which are equal to interest rate $r$ ), and where the principle scope is to have increasing monopoly rents (and therefore profits $\left.\pi_{t}\right)$. On the other hand, the evolutionary models present an entrepreneur who minimises the unit production costs (per investment unit) related to the investment made, where the income distribution is at the heart of firms' investment decisions, in order to keep constant the share of profit along the time.

It is interesting to observe the variable of capital $(K)$, for neoclassical theory, when the basic model is extended (see Aghion and Howitt, 1998, chap. 3)[34]; this variable is the sum of the physical (machines, computers etc.) and human capital (in particular, scientific). For evolutionary theory, on the other hand, the variable of capital $(K)$ is the variable volume only of the physical capital necessary for planning the additional output. Again, the labour factor is a stock fixed with constant returns-to-scale in the neoclassical view, but in the evolutionary view it is, as are the other factors, not fixed, with increasing returns-to-scale, because there exist numerous possible technical combinations (perfect substitutability).

Another difference is the choice of relevant time horizon. Both consider the expectations, but their way of conceptualization is different. Neoclassical economics assumes that agents can accurately foresee the future and that they maximize their preferences on an infinite time horizon. Individual rationality (or so-called "rationality anticipated") responds only to future developments. Evolutionary economics, however, acknowledges bounded rationality and

\footnotetext{
${ }^{16}$ Coad (2007)[40] believes that a strategy of this type is rather "over-cooked" and should be seen as a "semi-empirical" analysis, because the interpretation of the regression results is greatly overshadowed by theoretical prejudices.
} 
limited plasticity in firm behaviour, and it prefers to explain current decisions in terms of past decisions that are embodied in current production routines. The future of firms is not known, it cannot be "rationally anticipated". As a result, a firm cannot make its investment decisions on discounted expected future returns over an infinite horizon. Hence, its investment is determined by its current financial performance. The financial market is "neutral" as a simple intermediary, whose role does not affect the growth rate. Therefore, ET models consider the financial market equilibrium as the expected return on capital equal to return on capital.

The dependence of firm growth on the current period of financial performance finds its answer in the mechanism of "replicator dynamics". Growth is imputed according to measures of "fitness" or "vitality" that can be presented formally by Fisher's "fundamental equation":

$$
\delta x_{i}=\alpha x_{i}\left(F_{i}-\bar{F}\right)
$$

where $\delta$ is the variation in the infinitesimal interval $\left(\mathrm{t}, \mathrm{t}+\delta\right.$ t); $x_{i}$ represents the market share of firm $I$ in a population of competing firms; $F_{i}$ is the level of "fitness" of the considered firms (i.e. operating margin); $\alpha$ is a parameter; and $\bar{F}$ is the average fitness in the population. This equation favours the average firms with increasing market share, whilst reduces the presence of weaker and less profitable firms. A further difference concerns the characterization of the firm. In the neoclassical view, firms are assumed to be rational optimizers (though perfectly efficient firms can be considered unrealistic) and the relationship between growth and finance is introduced as endogenous factor that can affect the growth path, in line with the Schumpeterian view. On the other hand, in the evolutionary view, firms struggle against each other for growth opportunities ${ }^{17}$ and their growth is limited only by their ability to finance such growth ${ }^{18}$.

\footnotetext{
17 "Firms exist to grow"

${ }^{18}$ While in the neoclassical framework it is acceptable that if the information asymmetries were eliminated, financing constraints would disappear. For evolutionary economists, firms remain eternally financially constrained, irrespective of information asymmetries, simply because they would always prefer to be a little larger than they currently are.
} 
Predictions from evolutionary economics are also in line with those originating in the behavioural finance literature. In this view, firms are quite willing to spend free cash flow on innovative projects but are much less enthusiastic about having to resort to external finance. As a result, changes in cash flow would be positively associated with changes in investment. Finally, neoclassical theory conceptualizes growth as a deterministic process in which causality is clear-cut, and policies can be built on an understanding of time-invariant determinants of growth patterns. In contrast, in the evolutionary view, contingencies and specific historical circumstances play a greater role, and causal mechanisms that prevail in one period may be subject to endogenous change in the next.

\section{Some evidence}

Economic development creates demands for particular types of financial arrangement, and the financial system responds automatically to these demands. Robinson (1952, p. 86)[41] declares that "where enterprise leads finance follows". An interesting example is Pagano (1993)[35], who presents how to capture the potential effects of financial development on growth using the simplest endogenous growth model (the "AK" model), in which aggregate output is a linear function of the aggregate capital stock. If intermediation activity is increased, the social actors (firms and consumers) are stimulated to invest mostly in new innovation projects with greater profit returns. However, some economists do not believe that the finance-growth relationship is important $^{19}$. Many financial studies analyze how economic growth affects financial system development through growth-promoting financial intermediaries, including the stock markets (see, for example, Greenwood and Jovanovic, 1990; Greenwood and Smith, 1997)[37][42]. However, an embodied insight also seems to point out that there is an inverse relationship between growth and finance; it is already possible to find this view in Levine (1997, p. 703)[43], when assets generically:

\footnotetext{
${ }^{19}$ In the opinion of Lucas (1988, p.6)[21], more contemporary economists (in particular those who take the evolutionary approach) of innovation have largely neglected the relationship between finance and innovation.
} 
"...economic growth provides the means for the formation of growth-promoting financial intermediaries, while the formation of financial intermediaries accelerates growth by enhancing the allocation of capital."

A growing volume of literature shows that differences in how well financial systems reduce information and transaction costs influences saving rates, investment decisions, technological innovation and long-run growth rates. A comparatively less developed theoretical literature also demonstrates how changes in economic activity can influence financial systems. The major alternative approach to studying finance and economic growth is based on the seminal contributions of Gurley and Shaw (1955)[44], Tobin (1965)[45], and McKinnon (1973)[46].

Nevertheless, the weight of evidence suggests that financial systems are a fundamental feature of the process of economic development and that a satisfactory understanding of the factors underlying economic growth requires a greater understanding of the evolution and structure of these systems (Robinson 1952, pp. 67-142)[41].

Financial intermediation can affect economic growth by acting on saving rates, on the percentage of savings channeled to investment, or on the social marginal productivity of investment. Financial development usually has a positive effect on growth, but there are exceptions: improvements in risk-sharing and in the household credit market may lower saving rates, and hence the growth rate. Some researchers have analyzed how financial intermediation arises and develops endogenously in the context of economic growth: Goldsmith (1969)[47], McKinnon (1973)[46], Shaw (1973)[48], Greenwood and Jovanovic (1990)[37], Bencivenga and Smith (1991)[49], Devereux and Smith (1991)[50], Saint-Paul (1992)[51], Jappelli and Pagano (1992)[52], Roubini and Salsa-y-Martin (1992)[53] and King and Levine (1993a, 1993b and 1993c) [36]. 
Empirical studies have been undertaken, primarily based on large-scale cross-country regressions, to analyze the relationship between financial systems and economic growth. Unfortunately, this approach is data-driven rather than theory-driven and often many of the estimation results are sensitive to a small number of observations in a large sample. However, empirical research has lagged behind theoretical development, and the evidence that does exist is often ambiguous although some of the basic theoretical propositions that have been advanced. Most of these studies of finance and growth seek to relate the level of development and structural characteristics of the financial system to aggregate economic activity. Consistent with the dominant approach taken in the neoclassical growth theory, economic development is understood as an undifferentiated quantity generated by an aggregate production function.

Important weaknesses become evident when the economics of finance enters into contact with the dynamics of innovation. Most of the models used treat economic growth as if it was generic across the economy and over time. Typically, they make no allowance for variation and change in the organizational and institutional contexts in which financial resources are allocated and employed to facilitate economic growth. As a result, contemporary analyses of finance and growth make no reference to the structural composition and evolution of the economy and, therefore, ignore what Schumpeter regarded as the essential characteristic of the process of economic development; that is, its lumpiness over time and across sectors. The relationship between finance and growth is understood in terms of the influence of the quantity of finance provided and the price at which it is supplied; on the "amount" of economic growth. Therefore, research on finance, innovation and growth should pay greater attention to the role that contextual factors play in shaping financial relationships. "Who gets financial resources, when they get them, how they use them and other factors that can only be identified by making qualitative distinctions among enterprises, time periods, and investments, are likely to be more important than the overall quantity of financial resources that is invested in an industry." (O’Sullivan, 2004)[14]. 
However, there are some exceptions to the general rule. Recent studies that incorporate sectoral differences in their analyses of finance and growth tend to overlook the importance of these contextual factors. Some recent works have extended our knowledge about the casual relationship between financial development and economic growth. A similar Schumpeterian analysis of finance and technology is found in several recent empirical articles by Boyan Jovanovic and his co-authors on the relationship between the development of the stock market and technological revolutions in the US economy (Greenwood and Jovanovic, 1999; Hobijn and Jovanovic, 2001) [54][55].

In addition, Rajan and Zingales (1998)[56] differentiate between industries in terms of their investment and financing behaviour, arguing that their financial requirements are technologically determined:

"There is a technological reason why some industries depend more on external finance than others. To the extent that the initial project scale, the gestation period, the cash harvest period, and the requirement for continuing investment differ substantially between industries, this is indeed plausible."(Rajan and Zingales, 1998)[56].

Their main hypothesis is that industries that are more dependent on external finance should grow faster in countries with more developed financial markets and intermediaries. Several other studies have followed Rajan and Zingales in discriminating between industries in terms of their demand for finance (for example, Beck and Levine 2002 and Carlin and Mayer 2003)[57][58].

The central implication of this disaggregated approach to the relationship between finance and growth is that the economic impact of financial systems may be reflected not only in aggregate rates of economic growth but also in the differential development of particular industries. The task of analyzing the relationship between the financial system and the structural evolution of the economy has not been treated in any detailed way in these studies. 
This implies that the results achieved so far in this field constrain the measurement capacity of the empirical research; this is not sufficient to explain the relations between financial systems, innovation and growth.

Finally, whatever the circumstances we can concur with Levine (1997)[43] that: "a growing body of work demonstrates a strong, positive link between financial development and economic growth, and there is even evidence that the level of financial development is a good predictor of future economic development".

A growing body of empirical analysis, including firm-level studies, industry-level studies, individual country-studies, and broad cross-country comparisons, demonstrate a positive link between the functioning of the financial system and long-run economic growth; additionally, financial development may predict growth simply because financial systems develop in anticipation of future economic growth. However, scholars will not have a sufficient understanding of long-run economic growth until they understand the evolution and functioning of financial systems. This conclusion about financial development and long-run growth has an important corollary: "Although financial panics and recessions are critical issues, the financegrowth link goes beyond the relationship between finance and shorter-term fluctuations" (Levine, 1997 pp.721)[43].

Before the 2007 economists believed that economic productivity variations were the main short term variable to determine the level of investment into the firm system. Therefore, analysis of the relationship between economic growth and finance became their primary research interest. In fact, in most work financial system development is a function of economic growth, overlooking the inverse relationship (see figure 1).

Figure 1 - Synthetic description of the growth-finance and finance-growth relationship.

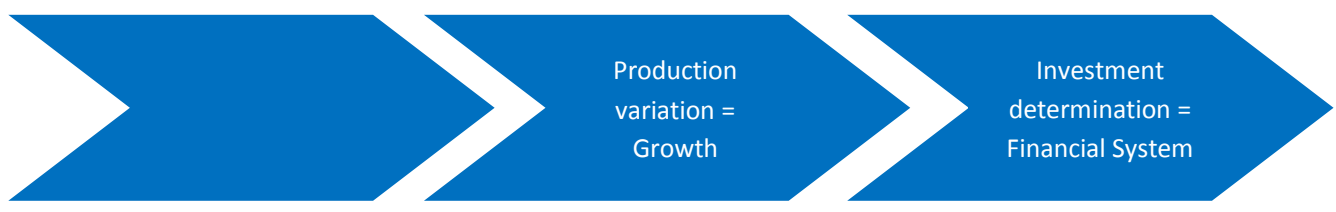




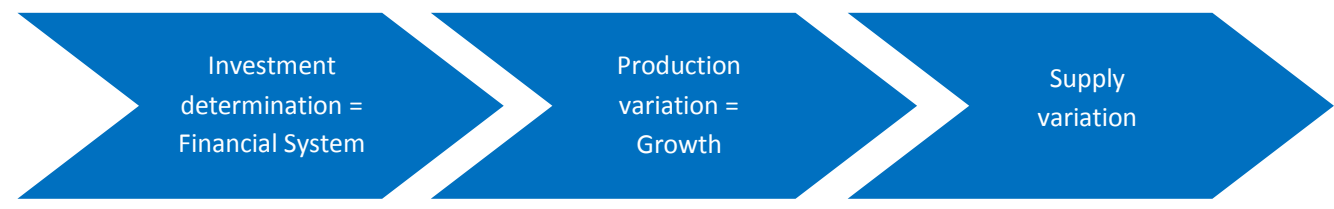

The new core of the analysis in the economic field is to understand the role of the financial system in the inverse relationship (finance - growth rather than growth - finance). It collects and distributes purchasing power, reduces information asymmetries, improves resource allocation and reduces the transaction costs. The rapid technological development of the financial system has opened a heated discussion about the relationship between finance, innovation and growth; in particular, its capacity to manipulate economic chance (finance/political power) by the creation of an endogenous "money bank".

\section{How do finance and the financial system interact to}

\section{affect economic growth?}

As discussed in the introduction, the main research questions are how do the economic and the financial systems interact to affect economic growth? And, is there a profound difference between sociological and technological definitions of the financial system? The new perspective seems to entail a new "greedy" economic status, where the financial state determines the growth path. Therefore, the mainstream growth-finance relationship is inverted. 
The Brandl $(1998)^{20}[59]$ working paper gives us an interesting insight that might draw our analysis path. The core of his idea is the link between the concept of the poverty trap and financial institution development. He explains that in low-income areas, where there are absence or weaknesses in the economic system of financial institutions, people can only save money "under the mattress". Entrepreneurs cannot easily borrow funds. Thus, an economy with a lack of financial institutions cannot optimally attract savings and, for this reason, will suffer from low saving rates. This will lead to a low level of investments, and the economic system will have slow or no economic growth. Consequently, this cycle delays financial institution development. Therefore, in Brandl's perspective there seems to exist a financial institutioneconomic growth relationship. In other words, economic growth increases proportionally to financial institution growth. In addition, different strands of literature, in particular, the financial literature, consider this relationship to be true. Conversely, to the Brandl hypothesis, what happens if an economic system has a "greedy" financial system with a high level of savings invested? Does the presence of "greedy" institutions reflect a highly-civilized financial system? And if the two "faces of the same coin" do not coincide, can the economy generate a sort of "wealth trap"? This could be possible.

The label "greedy" underlines the real status of the financial system today. It is characterized by financial trading activity which has a strategic self-gain motivation. Currently, the financial market is characterized by complexity. It is a liquid market, where supply and demand match automatically. The financial intermediary plays the role of insuring the liquidity and earns money by managing the flow of investments. The technological revolution that started in the 1970s/80s is the basis for this development. In fact, the "IT network economy" has become the place where it is possible to trade longer, in smaller volumes and faster.

As the scheme (see figure 2) shows, when the economy follows a so-called virtuous cycle, the presence of a highly-technological level of financial institutions operates beneficially, with a high level of savings put into productive use in the economic system, and this spurs a highly

\footnotetext{
${ }^{20}$ Brandl, M.W. The Role of Financial Institutions in Long Run Economic Growth. Presented at Soochow University Department of Economics Workshop, Taipei, Taiwan, December 1998[59].
} 
productive level of investment and funding for innovation projects. A high-growth level results. However, the alternative perspective seems to entail new "bad" cycles, in which the financial state determines the growth path. As a result, the growth-finance relationship is inverted. The main new hypothesis is that an economy in which financial institutions are greedy currently exists, and there is the possibility of a switch from a virtuous cycle to an anticompetitive greedy cycle. If the increasing political power of the financial markets (an externality of the evolution of the financial system) is not correctly managed (and thus it is possible to speak of the increasing "political power" of the financial system), the relationship will run in the opposite direction to the virtuous cycle, activating a wealth destroying cycle ${ }^{21}$. What we label here the "wealth trap" differs from the short-term Keynesian "liquid trap". It is the consequence of the presence of a "greedy" and "technologically advanced" financial system within the economic system. The Keynesian "liquid trap" is a consequence of the "wealth trap". It encapsulates a "political/market power" concept (of the technologically advanced financial system) which manipulates the growth path. If it pursues its speculative interests, it captures the wealth created in the cycle and incorrectly allocates capital. The real economy would suffer from the wealth created in the liquid trap and slowly slide into a negative growth. The financial markets can implement speculative activities. The set of financial markets in the current system of capitalism tends to focus on different and specific activities at different times, creating a "speculative bubble". At a certain point, the system breaks down (because someone is not able to pay his obligations), triggering a "domino effect". Temporal shocks and financial crisis occur in the economy, which can transform a "virtual" crisis to a real one. It is important to remember that today we are in a global macroeconomic system. Therefore, if a crisis starts at a point of global financial system, it contaminates all the global macroeconomic system. The main consequences of a crisis status are: 1) the bank system in particular and the financial system in general cut funding; 2) a credit crunch (also known as credit squeeze or credit crisis) and confidence falling

\footnotetext{
${ }^{21}$ It has a sociological and psychological foundation: those that govern the financial institutions in an advanced financial system can decide to abuse their privileged positions to reach highly powerful market levels. At these levels, particular information is easily accessible from agents, because the advanced system allows the extreme lowering of information costs. Although the presence of law, the badly human actions (dictate by avidity), may spur the economic system versus a perverse circuit.
} 
occur; 3) firms and households cannot easily obtain loans; 4) firms cannot make investments for ordinary productivity or to finance innovation projects; and 5) as a result, a slowdown of economic growth or, in the worst case, a move towards recession, with an important loss of wealth in terms of growth.

The advanced financial system facilitates financial product differentiation (through financial engineering), making a deep market segmentation. The financial markets continue to produce a multitude of new products (derivatives, alternative risk transfer products, exchange traded funds, and variants of tax-deductible equity) ${ }^{22}$. Following the bad path, the financial system has today put in place a discriminating monopoly in which market power and political power are tightly linked. It uses this monopolistic position and its market/political power to increase selfgain and maximize economic rent. It, therefore, captures consumer surplus. Good financial innovation improves risk management and reduces transactions costs. In contrast, bad financial innovation facilitates market segmentation and rent seeking speculators. Through a kind of accelerator effect, positive economic rent opportunities created by bad financial innovation and ongoing segmentation, increase information asymmetries. This in turn increases the possibility of defaults and the likelihood that a financial crisis will become an economic crisis. In addition, the conflict between public interest and private interest seems likely to be the reason for the switching between good and bad cycles. When private interest "captures" the public interest, it is highly likely that speculative finance will build up as predicted by Minsky (1982)[5]. This point needs to be investigated thoroughly. However, how can the virtuous cycle be restored? A virtuous cycle might reasonably be restored following a crisis after the government reregulates in the interests of taxpayers and voters. The model thus has political economy dynamics with a non-linearity by which the system can flip from "good" to "bad" cyclical equilibrium.

\footnotetext{
${ }^{22}$ A longer view suggests that financial innovation is an ongoing process whereby private parties experiment to try to differentiate their products and services, responding to both sudden and gradual changes in the economy (Tuffano, 2002).
} 
Figure 2 - Representation of the virtuous cycle and wealth trap.

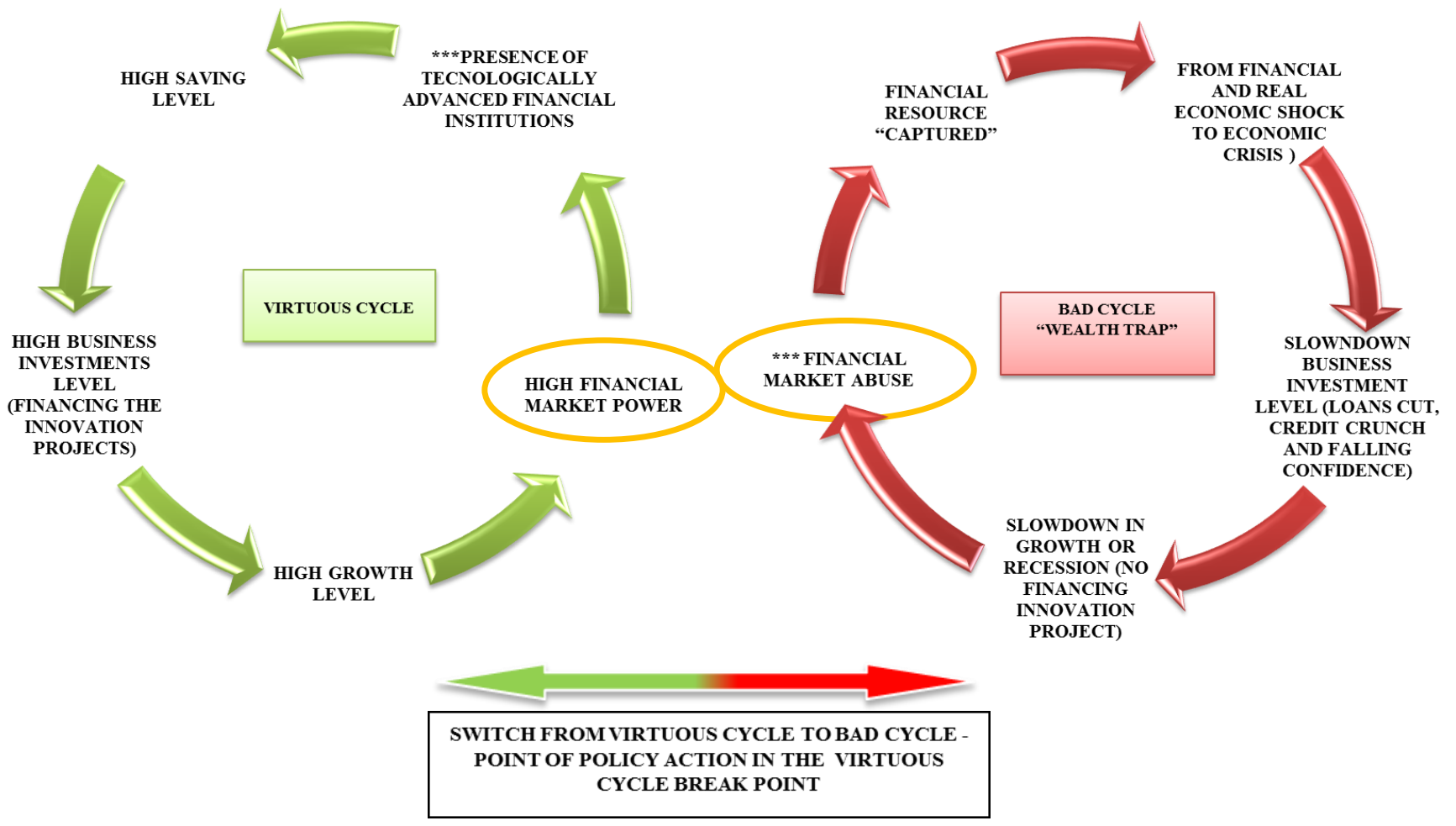

Source: Author's elaboration

Note: $(* * *)$ Start point of the cycles Source: Author's elaboration

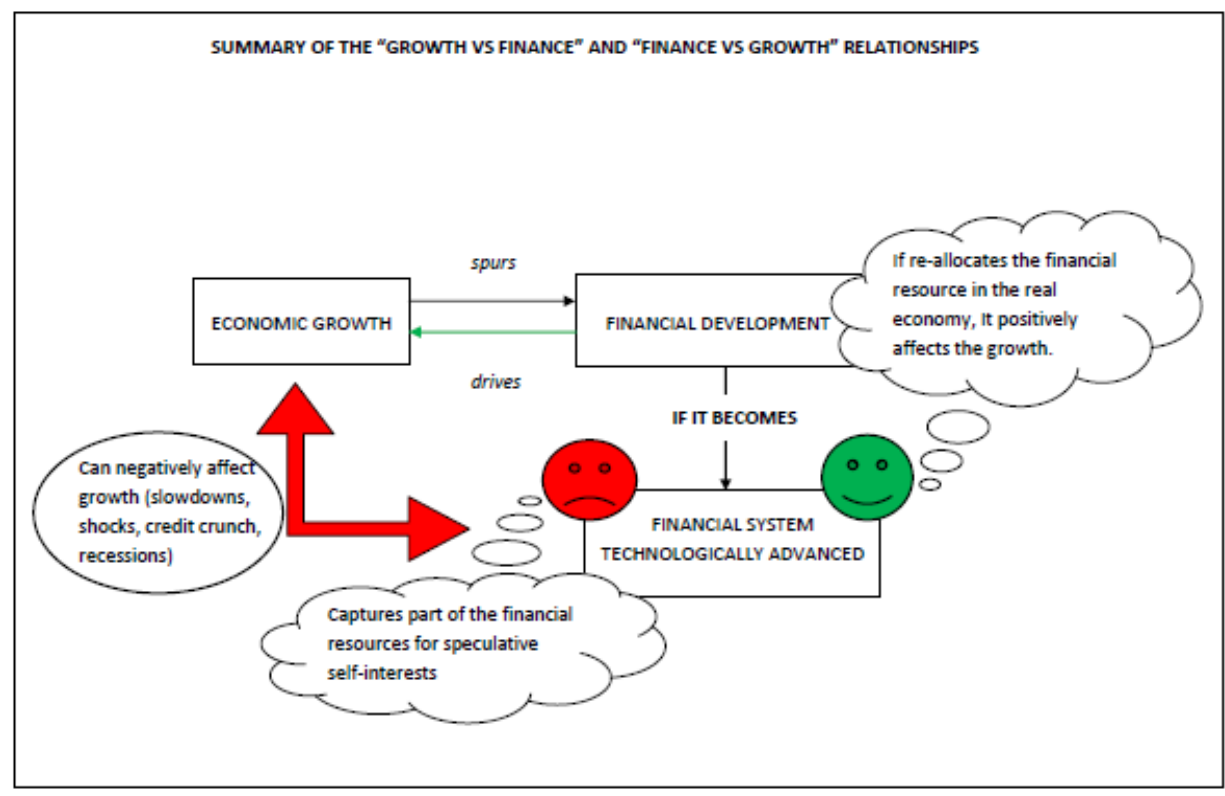




\section{A further step to establish the basis of a new financial}

\section{perspective: methodological notes}

The next step in this discussion is to build a dynamic non-linear multi-agent model that explains and shows the existence of the "double cycle" and simulates it around the finance - innovation growth relationship. The quantitative analysis of numerical simulation (Agent-Based Model ABM methodology) of Raberto et al. (2008)[60], Delli Gatti et al. (2011)[61], Dosi et al. (2011)[62], and Erlingsson et al. (2013)[63] is preferred. The aim is to develop a model drawn on the ET models that helps to understand and explain the behavioural causes that create the a state of crisis in the economy (without ignoring the financial consequences on the innovation process). In this way, the theoretical gap in ET concerning the importance of financial markets in the economy can be filled. ABM methodology is ideal for this investigation and it is used to simulate the actions and interactions of autonomous agents (both individuals and collective entities, such as organizations or groups). It combines elements of game theory, complex systems, computational sociology, multi-agent systems and evolutionary programming. With the use of Monte Carlo Methods, it introduces randomness.

The future extent of this analysis will explain how an advanced financial system affects the main macroeconomic variables that are decisive for an economy. The model will take some of the useful, interesting and more realistic insight from the theories studied (neoclassical and evolutionary) in this survey. It will, therefore, develop equations that make to meet the NGT and ET approaches. In this step of the study, it is not necessary to implement a data-driven model (calibration), which in the ABM approach is consequential, but not strictly necessary, to the numerical experimentation. Therefore, as the first step we will create a numerically-based model by computer simulation to investigate the nature of the finance-growth relationship.

From a general viewpoint, without here explaining the model structure in detail (this will be next exploration development), and starting with the Schumpeterian-neoclassical endogenous model and the Schumpeterian-evolutionary model (the Aghion and Howitt, 1998 and Villemeur, 
2008 models)[34][13], it is possible to identify the main elements which constitute the skeleton of the model.

1) Romerian "Horizontal differentiation" (1990)[18] in which each new innovation embodies the previous one.

2) Heterogeneous agents, which will simultaneously maximize profits (for investment units), with increasing return on capital, and also minimize the costs for investment units with a minimum share of constant profits, as insurance for the risks when choosing new combinations (innovation).

3) "Bounded rationally" assumed in a temporal horizon $(t, t+d t)$. Entrepreneurs make their current decisions in terms of past ones. Hence, investment decisions are determined by the current firm's production routines and financial performance. Firms always wish to be a little larger than their current status.

4) In this context, the key role of the financial system is very important because it greatly influences entrepreneurs' expectations of the future financial performance of firms; it, therefore, weighs on entrepreneurs' investment decisions.

5) The financial system evaluates firms; this reduces the information asymmetries and transaction costs (see Levine, 1997)[43], and facilitates fundraising for the financing of innovation, using a "replicator dynamic" as a firm's fitness measure. It would also be interesting to insert into the model a qualitative measure about a firm's activities. Both could estimate and identify the innovation projects to be funded.

6) Imperfect competitiveness is assumed in the final good market and the financial market.

7) Labour and capital factors will be considered variable over time.

8) Given the presence of the technologically advanced financial system, firms choose to take external financing rather than use internal cash flow. Therefore, they will prefer to use the cash flow, according to the principle of capital distribution, to invest it in financial activities (or products) and to gain interest; in this way, they balance their risk 
axis (i.e. between internal and external financing). In this mechanism, it might be possible to find reasons for the origins of a crisis.

9) In the same way, the financial system, through its habits of diversification, moves forward the risk axis and conducts speculative activities ${ }^{23}$. During periods of "euphoria", the financial system does not look responsibly at risk and, thus, banks expand, through the credit and the securitization ${ }^{24}$ the speculative boom. However, when the trend changes, bankers cut credit and greatly aggravate market difficulties. Therefore, the financial system is not a simple intermediary by which capital returns pass, but it is a place where new "bank money" is made and put into the economic system, affecting the growth rate.

10) The public sector imposes taxes on a firm's profits and the financial rent. The Central Bank makes monetary policy actions.

Given the above essential assumptions, which will be developed and expanded, the model will go on to show the quantitative analysis according to the methodology chosen.

\section{Conclusions}

Understanding financial resource demand and supply and the role of financial institutions (not only the banking system) is vital to explain the relationship between finance and growth. It is very important also to take into account the important key role of innovation. For financial institutions in their lender role to firms it is central to understand their weight in the real economy and because some types of firms are privileged to access the financial resource more easily than other by the financial system, while others are not. Many today believe that the periodic crises in the economic system are made much more severe by problems specifically in the banking sector and financial market inefficiencies in general and are again re-examining the

\footnotetext{
${ }^{23}$ The set of financial markets in the current system of capitalism tend to focus on different and specific activities (banks, raw materials, oil, etc...) in different times. The purpose of this activity is to increase the value of these assets for speculation. This is done through the concentration of the bank loading in certain sectors. For this reason, we see a financial economy, away from the real economy, which switches from bubble to bubble.

${ }^{24}$ Securization is a structured finance process in which assets, receivables or financial instruments are acquired, classified into pools, and offered as collateral for third-party investment.
} 
role that the financial markets play in economic growth (for example, Ross Levine, 1997, 1996, 1991; King and Levine 1993a, 1993b, 1993c and Pagano, 1993)[43][64][65][36][35]. On the other hand, more economists have become more sceptical about the role of the financial sector in economic growth (Robinson, 1952; Lucas, 1988)[41][21].

The frictions created by the economic system (idiosyncratic risk, liquid risk, informational asymmetries, transaction costs) spur the development of the financial system and institutions. The link between finance and economic growth arises because the projects with high-return potential need long-term capital. The financial system assures the capital funding. However, less investment is likely to occur in high-return projects when the financial system cannot guarantee liquidity in the economic system. This is the current situation in the post-crisis economy; indeed, the lack of liquidity (which increases the lack of confidence) has generated lower investment in innovation projects. In this survey, the two most relevant approaches emerge: "Evolutionary Theory" (ET) and "New Growth Theory" (NGT), which share the same inspirations from the thoughts of Schumpeter. In fact, Joseph Schumpeter (precursors) focused on resource allocation, especially financial resources, which was central to his study of innovation. The NGT theorists consider endogenous the role of financing factors and financing intermediaries. In contrast, ET does not consider the finance question, because these theorists are inspired by the Schumpeterian analysis that characterized the second part of his studies, where he deliberately neglected the important role of the financial system in the innovation process. This is a relevant gap. Nevertheless, ET theorists disagree on the behavioural foundations underlying these respective theories. These approaches differ less in their views on the importance of innovation for growth. Two representative models have clarified the main quantitative and qualitative differences and similarities (Aghion and Howitt, 1998 and Villemeur, 2008)[34][13]. The identification of the main demand and supply basic patterns of the financial resource is of primary importance to understand how they affect the dynamic of the economy. This result is obtainable only through integration of the qualitative and quantitative dimensions. In fact, this integration is an important gap in the literature, in which many works 
are empirical research focused on statistical analysis which is data-driven and on country differences (in large-scale cross-country regression). These analyses have not kept pace with theoretical developments, and the evidence that does exist is often ambiguous.

Hence, the next step is to build an agent-based model and simulate it around the finance innovation - growth relationship. The goal is to understand and explain the behavioural causes that create a crisis state in the economy, but without ignoring the aspect of innovation. The main hypothesis is that the current economy is one in which financial institutions are greedy and that there is a possibility to switch from a virtuous cycle to an anticompetitive greedy cycle, where financial and political powers are linked tightly.

The model should identify the real causes of growth and clarify if there is a deep difference in economics meaning between sociological and technological definitions of the financial system. The conflict between public and private interests seems to be the reason for the switching between good and bad cycles. All this elements of analysis might be a reasonable approach to start the analysis about how a virtuous cycle could be restored in the economy.

\section{References}

[1] Schumpeter J. A. (1934). The Theory of Economic Development. Cambridge: Harvard University Press

[2] Shackle G. L. S. (1967). The years of high theory: invention and tradition in economic thought 1926-1939. CUP Archive.

[3] Aghion P. and Howitt P. (1992). "A Model of Growth Through Creative Destruction." Econometrica, 60: 323-351.

[4] Nelson S. G. and Winter R. R. (1982). “An Evolutionary Theory of Economic Change.” Cambridge: Mass.: Harvard University Press.

[5] Minsky H. P. (1982). Can "It" Happen Against? Essays on Instability and Finance. Armonk, N.Y.: M. E. Sharpe. 
[6] Modigliani F. and Miller M. H. (1958). The Cost of Capital, Corporate Finance and the Theory of Investment. American Economic Review, 48, 261-97.

[7] Hayek, F. A. (1931). "Reflections on the Pure Theory of Money of Mr. J. M. Keynes." Part I, Economica 33 (August).

[8] Schumpeter J. A. (1939). Business Cycles: A Theoretical, Historical and Statistical Analysis of the Capitalist Process. New York: McGraw-Hill.

[9] Keynes J. M. (1936). The General Theory of Employment, Interest and Money. Macmillan, London.

[10] Shackle, G. L. S. (1968) Uncertainty in Economics, and Other Reflections. Cambridge: University Press.

[11] Shackle, G. L. S. (1969) Decision, Order, and Time in Human Affairs. Cambridge: University Press.

[12] Shackle, G. L. S. (1949). Expectation in Economics. Cambridge: University Press.

[13] Villemeur A. (2008). "Economic Growth, an Evolutionary Process that gives rise to an attractor." 12th International Schumpeter Society Conference, Rio de Janerio.

[14] O'Sullivan M. (2004). "Finance and Innovation." In The Oxford Handbook of Innovation, 240-265. Oxford: Oxford University Press.

[15] J.A. Schumpeter (1942). Capitalism, socialism and democracy. Harper, New York.

[16] Verspagen B. (2004). "Innovation and Performance." In Innovation and Economic Growth, 487-513 (Chp. 18). The Oxford Handbook of Innovation.

[17] Romer P. (1986). "Increasing Returns and Long Run Growth.” Journal of Political Economy, 8: 1002-1037.

[18] Romer P. (1990). “Endogenous Technological Change.” Journal of Political Economy, 98: S71-S102.

[19] van den Bergh J. C. J. M. (2004). "Evolutionary Analysis of the Relationship between Economic Growth, Environmental Quality and Resource Scarcity.” Tinbergen Institute Discussion Paper, 048/3. 
[20] Solow R. M. (1956). “A Contribution to the Theory of Economic Growth.” Quarterly Journal of Economics, 65-94, vol. 70.

[21] Lucas R.E. (1988). “On the Mechanics of Economic Development." Journal of Monetary Economics, 22(1), 3-42.

[22] Grossman, g. m. and Helpman, e. (1990), "Comparative Advantage and Long-Run Growth”, American Economic Review, 80,796-815.

[23] Grossman G. M. and Helpman E. (1991). Innovation and Growth in the Global Economy. Cambridge: Mass.: MIT Press.

[24] Helpman E. (1998). General Purpose Technologies and Economic Growth. Cambridge: Mass.: MIT Press.

[25] Dosi G. (1982). "Technological Paradigms and Technological Trajectories." Reseach Policy, 11:147-162.

[26] Silverberg G., Dosi G. and Orsenigo L. (1988). "Innovation, diversity and diffusion: a self-organization model.” Economic Journal, 98: 1032-1054.

[27] Conlisk, J. (1989). “An Aggregate model of technical change.” Quarterly Journal of Economics, 104: 787-821.

[28] Chiaromonte F. et Dosi G. (1993), "Heterogeneity, competition and macroeconomic dynamics “, Structural Change and Economic Dynamics, 4, p. 39-46.

[29] Silverberg G. and B. Verspagen (1998). "Economic Growth and Economic Evolution: A Modeling Perspective", in F. Schweitzer and G. Silverberg (eds), Selbsorganisation, Duncker \& Humblot. 9, Berlin.

[30] R. M. Goodwin (1967). "A Growth Cycle", in C. H. Feinstein (ed.): Socialism, Capitalism and Economic Growth, Cambridge, pp. 54-58.

[31] Malerba F., Nelson R., Orsenigo L., and Winter S. (1999). ""History-Friendly" Models of Industry Evolution: The Computer Industry." Industrial and Corporate Change, 8: $3-40$. 
[32] Potts J. (2000). The New Evolutionary Microeconomics: Complexity, Competence, and Adaptive Behavior. Cheltenham: Edward Elgar.

[33] Dosi G. Freedman C. Nelson R., Silverberg G. and Soete L. (1988). Technical Change and Economic Theory. London/New York: Pinter Publisher.

[34] Aghion, P. and Howitt, P. (1998). Endogenous Growth Theory. Cambridge: MA. MIT Press.

[35] Pagano M. (1993). "Financial Markets and Growth: An Overview." European Economic Review, 37 (2-3) 613-622.

[36] King R.G. and Levine R. (1993c). "Finance, Entrepreneurship, and Growth: Theory and Evidence.” Journal of Monetary Economics, 32(3), 513-542.

[37] Greenwood J. and Jovanovic B. (1990). "Financial Development, Growth and the Distribution of Income.” Journal of Political Economy, 98: 1076-1108.

[38] Perez C. (2002). Technological Revolutions and Financial Capital: The Dynamics of Bubbles and Golden Ages. Cheltenham: Edward Elgar, 2002.

[39] Robinson J. (1954). "The Production Function and the Theory of Capital." Review of Economic Studies 21.

[40] Coad A. (2007). "Testing the principle of 'growth of the fitter': the relationship between profits and firm growth." Structural Change and Economic Dynamics, 18 (3), pp. $370-386$

[41] Robinson J. (1952). The Generalization of the General Theory. London: Macmillan, $67-142$.

[42] Greenwood J. and Smith B. D. "Financial markets in development, and the development of financial markets." Journal of Economic Dynamics and Control, 21.1: 145-181.

[43] Levine R. (1997). "Financial Development and Economic Growth: Views and Agenda." Journal of Economic Literature, Vol. XXXV, 688-726. 
[44] Gurley J. and Shaw E.S. (1955). "Financial Aspects of Economic Development." American Economic Review, XLV, pp. 515-538.

[45] Tobin J. (1965) . "Money and Economic Growth.” Econometrica, 33(4), 671-684.

[46] McKinnon R.I. (1973). Money and capital in economic development. Washington, DC: Brookings Institution.

[47] Goldsmith R.W. (1969). Financial structure and development. Yale University Press, New Haven, CT.

[48] Shaw E.S. (1973). Financial deepening in economic development. Oxford University Press, New York, NY.

[49] Bencivenga V.R. and Smith B.D. (1991). "Financial intermediation and endogenous growth." The Review of Economic Studies, 195-209.

[50] Devereux M.B. and Smith G.W. (1991). "International risk sharing and economic growth.” Department of Economic, Queen's University. Kingston, Ont.: Discussion paper no. 829 .

[51] Saint-Paul G. (1992). "Technological choice, financial markets and economic development." European Economic Review, 36, 763-781.

[52] Jappelli T. and Pagano M. (1992) "Saving, growth and liquidity constraints." London: CEPR, Discussion paper no. 662 .

[53] Roubini N. and Salsa-y-Martin X. (1992). "A growth model of inflation, tax evasion, and financial repression.” Working paper no.4062, May: NBER, Cambridge, MA.

[54] Greenwood J.and Jovanovic B. (1999). “The IT revolution and the stock market." National bureau of economic research, No. w6931.

[55] Hobijn B. and Jovanovic B. (2001). "The IT Revolution and the Stock Market: Evidence" American Economic Review, 85, pp. 1000-1020.

[56] Rajan R and Zingales L. (1998). "Financial Dependence and Growth." American Economic Review, 88(3), 559-586. 
[57] Beck T. and Levine R. (2002). "Industry growth and capital allocation: does having a market- or bank-based system matter?" Journal of Financial Economics, 64 (2), pp. $147-180$.

[58] Carlin W. and Colin M. (2003). "Finance, investment, and growth." Journal of financial Economics, 69.1: 191-226.

[59] Brandl M.W. (1998). "The Role of Financial Institutions in Long Run Economic Growth." The University of Texas at Austin: McCombs School of Business Department of Finance, Presented at Soochow University Department of Economics Workshop Taipei, Taiwan, December 1998.

[60] Raberto M., Teglio A. and Cincotti S. (2008). "Integrating real and financial markets in an agent-based economic model: an application to monetary policy design.” Computational Economics,147-162.

[61] Delli Gatti D., Desiderio S., Gaffeo E., Cirillo P. and Gallegati M. (2011). Macroeconomics from the Bottom-up. New Economic Thinking. Springer, Milan.

[62] Dosi G. Fagiolo G. Napoletano M. and Roventini A. (2011). "The Role of Technical Change, Finance and Public Policies in an Evolutionary Model of Endogenous Growth and Fluctuations." Paper presented at the DIME Final Conference 6-8 April 2011, Maastricht.

[63] Erlingsson E. J. et al. (2013). "Housing market bubbles and business cycles in an agent-based credit economy.” No. 2013-32. Economics Discussion Papers.

[64] Levine R. (1996). "Stock Markets: a Spur to Economic Growth.” Stock Markets, Corporate Finance and Economic Growth. World Bank Conference.

[65] Levine R. (1991). "Stock markets, growth, and tax policy." The Journal of Finance, 46, Sept. 1445-1465.

[66] Metcalfe J. S. (1998). Evolutionary Economics and Creative Destruction: Graz Schumpeter Lectures 1. Routledge: London and New York. 
Abramovitz M. A. (1870). "Resources and Output Trends in the United States since ." American Economic Review, 1956: 46: 5-23.

Bencivenga V.R. and Smith B.D. (1993). "Some Consequences of Credit Rationing in an Endogenous Growth Model.” J. Econ. Dynam. Control, 97-122.

Bernanke B. and Gertler M. (1990). "Financial Fragility and Economic Performance." Quart. J. Econ., : 105 (1), 87-114.

Coad, A. (2008). "Neoclassical vs Evolutionary Theories of Financial Constraints: Critique and Prospectus.” CES (Centre d'Economie de la Sorbonne) Working Papers 2008.08.

Coad, A. (2005). "Testing the principle of growth of the fitter: the relationship between profits and firm growth." Dept. of Economics, Emory University, Atlanta GA: Emory Economics Working Paper 05-31.

Devereux M.B. and Smith G.W. (1994). "International Risk Sharing and Economic Growth.” Int. Econ. Rev., 35(4), 535-550.

Fagerberg J. (1988). "Why growth rates differ in: G. Dosi, C. Freeman, R. Nelson, G. Silverberg and L. Soete." Technical Change and Economic Theory. London: Pinter Publishers.

Iwai K. (1984). "Schumpeterian dynamics, part I: an evolutionary model of innovation and imitation." Journal of Economic Behaviour and Organization, 5(2): 159-190.

Jubak J. (2007). “How far will the credit crunch spread?” Jubak's Journal, 2007: August 3. Maddison A. (2001). The World Economy: A Millennial Perspective. Paris: OECD Development Centre.

Merton R.C. and Bodie Z. (1995). "A Conceptual Framework for Analyzing the Financial Environment." In The global financial system: a functional perspective, 3-31. Boston: MA: Harvard Business School Press. 
Mulder P. and van den Berg J. C. J. M. (2001). "Evolutionary economic theories of sustainable development." Growth and Change, 32(4): 110-134.

Mullineux A.W. (1990). "Business cycles and financial crises." Bookboon.com (free download).

Nelson R. (1993). National Innovation Systems: a Comparative Analysis. Oxford: Oxford University Press.

Rebelo S. T. (1991). "Long-run Policy Analysis and Long-run Growth.” Journal Polit. Econ., 99(3),500-521.

Schumpeter J.A. (1942). Capitalism, socialism and democracy. Harper, New York.

Shaw, E.S. (1973). Financial deepening in economic development. New York: Oxford University Press, 1973.

Stiglitz J. E. (1985). "Credit Markets and the Control of Capital." J. Money, Credit, Banking, May 17(2), 133-152.

Whalen C. J. (2007). “A Minsky Moment." Public Policy Brief, The Levy Economics Institute of Bard College, No. 92.

Williamson S. D. (1987b). "Financial Intermediation, Business Failures, and Real Business Cycles.” J. Polit. Econ., 95(6),1196-1276.

Zanini A. (2000). Joseph A. Schumpeter. Milano: Bruno Mondadori, 2000. 